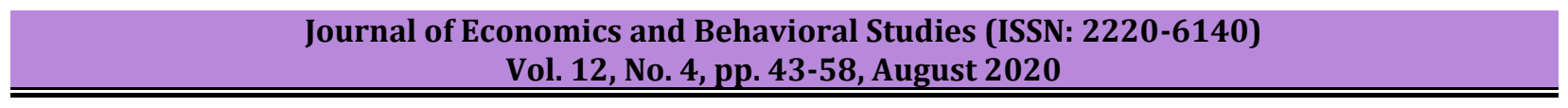

\title{
COVID-19 Outbreak and Behavioral Maladjustments: A Shift from a Highly Globalized World to a Strange World of Unique Isolationism
}

\author{
Matthew Abiodun Dada \\ Department of Economics, College of Management Sciences, \\ Federal University Agriculture Abeokuta, Nigeria \\ mattabeyvoice@gmail.com
}

\begin{abstract}
The outbreak popularly called COVID-19 which sneaked into the world system generally believed to have originated from China in the city of Wuhan towards the last quarter of the year 2019 in a manner yet to be unfold by the world powers has been judged to be a great threat to human activities and coexistence. The World Health Organization declared COVID-19 as a global pandemic between February and March, year 2020 and since then it has been a strange world. This paper examined the socio-economic changes and behavioral maladjustments resulting from this deadly disease. The demand and supply shocks as well as the use of fiscal stimulus from different countries and how some key variables respond are well analyzed and structured. The paper underlying some of the damages done to the socio-economic lives of people across the globe and highlight some recovery strategies and future prospects. It recommends spirituality as a winning strategy against carnality. The conclusion was drawn by emphasizing the supremacy of God in the fact that a microbe of invisible property could hastily change our world of global village to a strange world of isolated cities.
\end{abstract}

Keywords: COVID-19, global pandemic, fiscal stimulus, microbes, supremacy of God.

\section{Introduction}

The world received with great shock the news of an outbreak of a viral disease, called corona virus popularly known as COVID-19 which was declared a global pandemic by world health organization (WHO) in the second Week of March, year 2020. The acronym, COVID-19 was a derivative of the corona virus disease originated from the city of Wuhan in the People Republic of China toward the last quarter of the year 2019. From the acronym therefore, $\mathrm{CO}=$ corona, $\mathrm{VI}=$ virus, $\mathrm{D}=$ disease and $19=$ year 2019. It was like a child play, a microbe of invisible property could bring such a great misfortune to humanity despite all the advancement in technology and medicine across the known world. Where are the various detectives and remote sensors to prevent this deadly organism from wrecking its havoc on humanity? The world woke up one day to see a destructive virus causing a pandemonium and behavioral changes in our ways of life. The economic and social lives were brought to a standstill. The saddest thing is that no country irrespective of the level of development and technological sophistication was able to get immediate response to contain this deadly virus other than lockdown, social and physical distancing.

Then the concepts of economic lockdown, social and physical distancing were recommended as the only means of containing the spread of this evil virus. These no doubt have caused severe hardship and terrible pain for the entire mankind living on the planet earth whether developed or underdeveloped countries. The destructive consequences of COVID-19 and its spillover effects on the overall economies and human existence have been noted by authors such as, El-Erian (2020), Ozili and Arun (2020), Ozili (2019), Larry (2020), among others. Economic crises whether resulting from pandemic or otherwise can trigger civil unrest and psycho-social disorders and discontent in any society. See, Bermeo and Bartels (2014); Bagliano and Morana (2012); Giannakis and Bruggeman (2017); Giugni and Grasso (2016). The question of whether the outbreak of pandemic could cause a great economic downturn either at regional or global space has been addressed by authors such as; Horowit (2020) as well as Krueger, Uhlig and Xie (2020). Leading economic experts have also shared the same view, see, Financial Times (2020). The literature also suggests that during the period of upheavals, there is every tendency for government expenditure to rise above her revenue leading to a fiscal imbalance between expenditure and revenue. The regime of fiscal deficit becomes inevitable with the outbreak of pandemic of global magnitude. Many studies on government expenditure and revenue nexus have provided more information on government expenditure and revenue nexus, particularly, Dada (2013) as well as Dalena and Magazzino (2010). The recent outbreak of corona virus has certainly created the need for the government to spend more and earn low due to weakening power of tax payers to earn and pay taxes as a 
result of measures taken to contain the spread of the corona virus. This paper examined the social economic and behavioral changes associated with COVID-19, the various efforts to cushion the effects on the people and different scenarios such as trade-off between corona virus and hunger virus, the wealth gain versus health loss, the health gain versus wealth loss as the case is in many countries, psychological disequilibrium due to loneliness caused by lockdown and isolation and different socio-economic mal-adjustment.

The paper is specially written using a highly simplified approach in response to the sudden change in the workings of the world system since the arrival of COVID-19 pandemic in the planet earth and this serves as one of very few studies drawing attention of world leaders to the need to be God-dependent and learn to always consider spirituality as a viable option in tackling emergency instead of concentrating all efforts on carnality even when it produces little or no result. The paper has analyzed the socio-economics disequilibrium and behavioral maladjustment resulting from COVID-19 pandemic from point view of economic and spiritual man.

The remainder of this paper is structured as follows: following this introductory section is section two, which presents a brief literature review follows by section three which presents the analytical procedures, analyzes the disturbances resulting from the COVID-19 outbreak, that is, the global economic shocks and the application of fiscal stimulus and its efficiency scenarios in ameliorating the pain and hardship created by COVID-19 outbreak. Next is section four which highlights some of the strategies employed to cushion the effect of the deadly virus on the economy. This is followed by section five which highlights some of the lessons learnt against future occurrences while section six concludes the paper.

\section{Literature Review}

The world is of age and as one grows older and older each day, new experience is gained in addition to previously acquired experiences. For instance, if the world has finally ended up two years ago, the experience of COVID-19 would not have met it here but while still existing, anything could happen. COVID-19 is not the first pandemic to break out on a global space. The literature provide insight into the historical records of outbreak of pandemic that have taken hundreds of millions of people away from this planet earth. According to World Economic Forum (2020) as echoed in the work of Abel, Anik, David and Suraiya (2020), a pandemic called Antonine Plague killed five million people in the early time 165-180, another pandemic called Plague of Justinian broke out between 541-542 killing between 30 and 50 million people, another pandemic called Japanese Smallpox broke out between 735- 737 killing one million people, another pandemic called Black Death broke out between 1347-1351 killing 200million people, another pandemic called New World Smallpox in 1520 killing 56million people, another pandemic called Great Plague of London broke out in 1665 killing 100thousand people, another pandemic called Italian Plague broke out between 1629-1631 killing 1million people, another pandemic called Third Plague broke out in 1885 killing 12million people, another pandemic called Yellow Fever broke out in the late 1800s killing between 100 and 150thousand people, another pandemic called Russian Flu broke out between 1889-1890 killing 1million people.

Also, between 1918-1919, another pandemic called Spanish Flu broke out killing between 40 and 50mllion people, another pandemic called Asian Flu broke out between 1957-1958 killing 1.1mllion people, another pandemic called Hong Kong Flu broke out between 1968-1970 killing 1mllion people, another pandemic called HIV/AIDS broke out in 1981-date and has killed between 25 and 35million people, another pandemic called SARS broke out between 2002-2003 killing 770 people, another pandemic called Ebola broke out between 2014-2016 killing 11thousand people, another pandemic called MERS broke out in 2015-date and has killed 850 people. COVID-19, the latest pandemic broke out in the last quarter of 2019 and since then the world has witnessed a dramatic change. This historical account of pandemic outbreak provides the right information that pandemic outbreak is not new and hence COVID-19 has come and man will also overcome it just as previous outbreaks have been defeated. In order to throw more light into the nature of infection from COVID-19, a large number of studies, for instance, Atkeson, Kopecky and Zha (2000) estimate and forecast disease scenarios for COVID-19 using a Susceptible-Infected-Recovered (SIR) Epidemiological Models developed by Kermack, McKendrick and Walker (1927). The models identified three states of health, first, Susceptible (S) who is at risk of getting infected, second, Infected (I) who is contagious, and third, the 
Recovered (R) who has been previously infected but now has recovered. The dead people from the virus are said to be no longer contagious.

The assumption of the models is that those that are susceptible interact with infected people at a given rate and the people that are infected recover over time at a given rate and then acquired immunity. The models predict that eventually, the number of people that are susceptible start to fall since people continue to develop herd immunity against the virus. The probabilities associated with the different rates, that is, infection rate, recovery rate and mortality rate form the major parameters of the SIR models which help in simulating the efficacy of social and physical distancing rules. The missing fact in the SIR models as noted by another study is the overconcentration on public health outcome without considering economic outcome which could also triggered other health traumas. An attempt to solve one health problem which could create another health crisis. To address this problem, Eichenbaum, Rebelo and Trabandt (2020a) used a SIR-macro models to incorporate economic outcomes and confirm that the infection rate depends largely on the degree of interaction between agents when consuming or working and the possibility of contracting the virus by chance from asymptomatic carrier of the virus. The study also confirm the existence of incomplete information, infection externalities and risks across sub-population. In order to account for the incomplete information, Berger et al. (2020) develops a Susceptible-Exposed-Infectious-Recovered (SEIR) models based on Kermack et al. (1927). The study suggest that increasing testing of susceptible population should be put in place. To identify infected-asymptomatic patients and quarantining the subset of the population. For infection externality problem, Eichenbaum et al. (2020a) asserts that competitive equilibrium is not Pareto optimal as agents do not consider their actions affect the infection and mortality rate among other economic agents. In order to properly internalize the externality problem, the study suggests that the measures put in place to contain the virus are optimal if they are tightened over time in proportion to the spread of the virus. The study also noted that if a strict containment policy has been enforced right away from the beginning, it would have had a much more severe impact on the economy. Krueger Uhlig and Xie, (2020) has provided some explanation on how to flatten the curve of this pandemic, that is, how to reduce the infection rate. Some theoretical propositions on the behavioral responses to various changes in policy decisions as infection level changes have also been provided in the works of Quaas (2020) and Dasaratha (2020). The literature on this subject matter, though, very thorough and extensive, especially on the therapy and the economy, yet, there exist a gap in methodological approach. Therefore, this study fill this gap by approaching the topic from both the economic and spiritual man.

\section{Analytical Procedures}

This study employed microeconomic principles and rules to analyze the behavioral pattern exhibited in the wake of COVID-19 outbreak and the steps taken to contain the spread of the virus. The tools of analysis in this study are graphs and equations to convey the message of this paper. There are three agents involved in the drama caused by this pandemic. They are the household, business firm and government. The pandemic has caused confusions and commotion among these three agents because the three agents have different objectives and each would be interested in pursuing its own interest. This conflict of interest led to chaos and uproars that were experienced in many countries of the world. Government wants to maximize social welfare by ensuring lives and properties are secured, business wants to produce and maximize profit while the household wants to maximize utility. We could understand that these set of different objectives might be difficult to achieve during the pandemic period with the introduction of social and physical distancing as well as lockdown rule. The international and international airways were completely shutdown. Both the waterways and the highways were equally shutdown. Cross-border, inter-state and inter-city movements were completely proscribed. Government switched into action to embark on promulgating laws that violate the existing fundamental human right of individuals and business alike which they were enjoying in the preCOVID-19 period. All these have cumulated into the various crises experienced in many countries during the pandemic period.

Analysis of COVID-19 Outbreak and the Global Economic Shocks: Economics talks of shock when an unexpected or unpredictable event that affects the economy either positively or negatively occurs. In a more technical manner, a shock is an unpredictable change in exogenous factors which may influence endogenous economic variables. Exogenous factors are factors that are unexplained by economics itself but factors 
external to economics, they are taken as given. Empirical literature suggest that market failure often leads to economic shocks. COVID-19 has really distorted the workings of the market systems causing market failure of global magnitude. Economic recession has been suggested as the end-results of shocks. Many studies have suggested different factors causing economic recession. Among these include; Stiglitz, (2010), Chauffour and Farole (2009), Petrakos (2014), Glassman (2001), Di Quirico (2010), Honkapohja and Koskela (1999), Morales and Sachs (1989), Adeniran and Sidiq (2018), Bagliano and Morana (2012), Bermeo and Bartels (2014). The outbreak of COVID-19 pandemic has led to many hard decisions taken by governments across countries, see, Jonathan (2020). We have border closure in every country of the world, barring of international travels and movements, shutting down of interstate movement even within country and the entire lockdown that keep people inside their homes without having anything to do with others in order to observe the social distancing rule and even physical distancing within homes.

These are costly decisions which have been the possible sources of economic shock particularly in the transport sector and its aviation sub-sector as well as other sectors of the economy. COVID-19 therefore, would have had an adverse effect on the people due to changes in key macroeconomic variables such as price, output and employment. There have been government intervention in form of fiscal stimulus giving out to cushion this effect. The efficacy of this however, varies from one country to another and from one individual to the other due to the level of development which also determines the initial endowment both at individual personal and aggregative national level. The economies from across the globe varies significantly in their absorptive power, so the shock may have greater impact in some countries while the impact may be low in some other countries. Also the memory of the shock may live long in some economies while it dies out shortly in some others. How long the memory of COVID-19 outbreak will take is a function of the absorptive power of different economies across the world. Using initial saving both at household, business firm and government levels as well as aggregating at national level, variation exists and such variations may be significant, for example the gap in real per capita income varies significantly between developed and underdeveloped countries. So also there is significant income gap between the rich and the poor living in less developed countries. This reveals the picture of the dualistic nature of human existence on the surface of the earth. This variation will definitely affect the ability of people to cope under the lockdown and isolation strategies of containing the COVID-19 outbreak.

It could also be recalled that before COVID-19 outbreak, people were enjoying their full fundamental human rights, no restriction of movement, nothing like closure of borders, nothing like stay at home rule, no market constraint, nothing like under-capacity utilization where people are given limited time to operate, especially limited time to open shops, offices, markets, etc., so life was full of engagement and enchantment, utility maximization process is as shown in Figure 1. People can move from lower level of utility to a higher level. There could be movement from IC1 to IC2, from IC2 to IC3, from IC3 to IC4 as shown in the figure. These movements represent movement from lower level of utility to a higher level. The pre-COVID-19 period was full of hope and aspiration, balanced emotion, optimism and desire for the best. The utility was maximum at IC4 in the figure confirming the equilibrium state of the economy before the upset caused by the outbreak of COVID-19 global pandemic and the strategies put in place to contain the spread such as social and physical distancing, isolation and lockdown. These strategies have their opportunity cost in term of psychological disturbances due to uncertainty, job lost, solitary life and loneliness resulting to disutility in which case utility drops sharply in the opposite direction as shown in Figure 2. 
Figure 1: Indifference Maps Illustrating the State of a Rising Utility in the Pre-COVID-19 Period Y-Axis

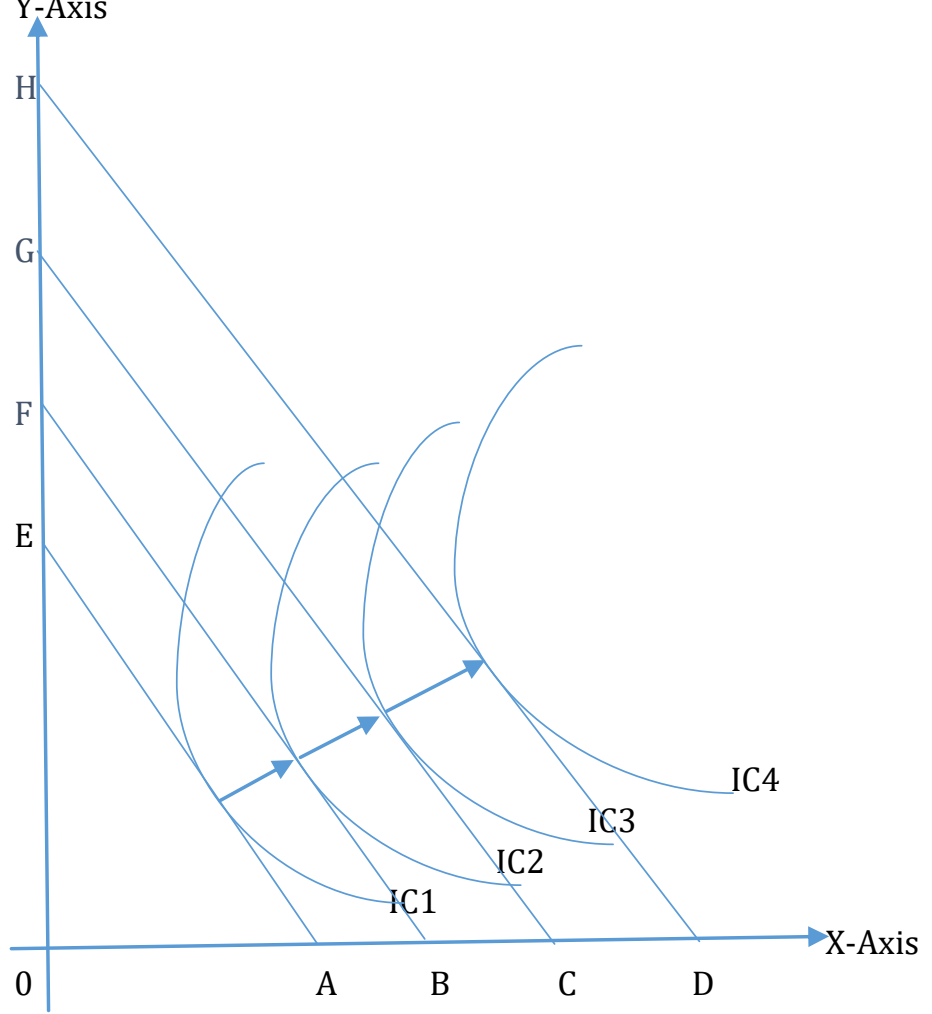

Figure 2: Indifference Maps Illustrating the State of a Falling Utility in the COVID-19 Period Y-Axis

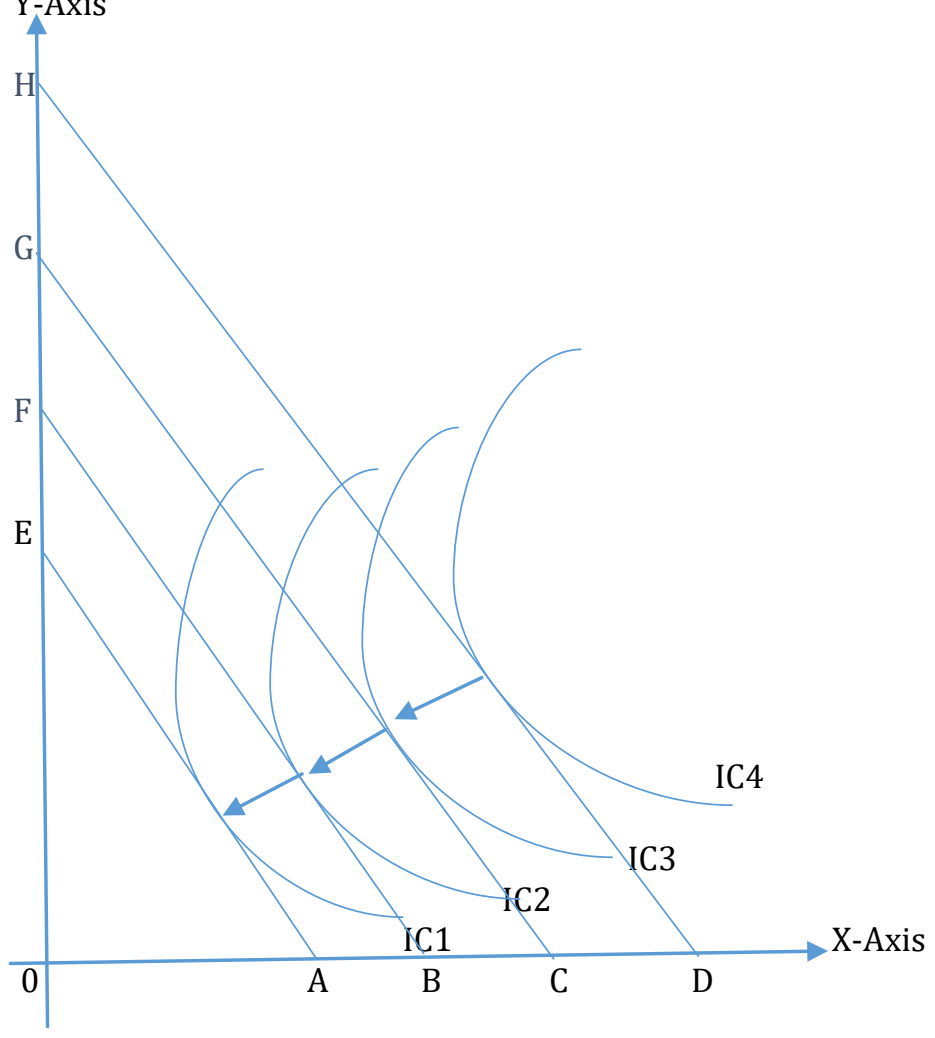


The pattern of consumption behavior in the pre-COVID-19 period will never remain the same due to condition imposed by budget constraint. In the pre-COVID-19 period, the budget line experienced outward shifts which imply gains in welfare but the outbreak of COVID-19 pandemic has led to inward shifts in budget line which imply welfare loss as the case is in the COVID-19 era when there was a significant job loss due to a sharp drop in economic activities. This is shown in Figure 3 and 4. Figure 3 depicts outward shifts in budget lines showing a rising utility while Figure 4 depicts inward shifts in budget lines showing a falling utility.

Figure 3: Budget Lines depicting Pre-COVID-19 Economic Condition

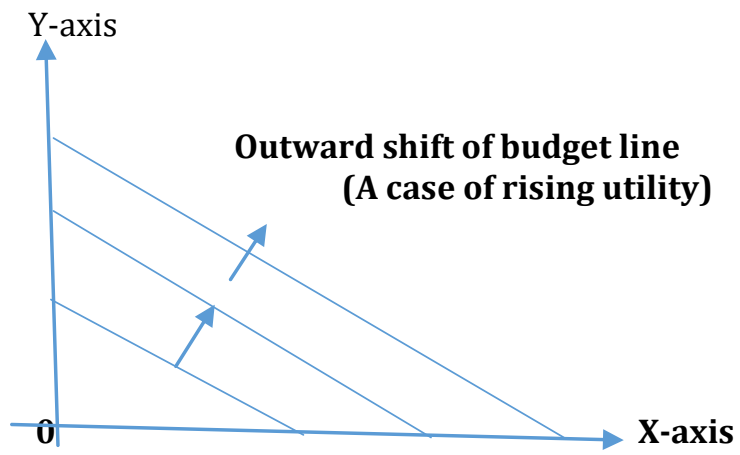

Figure 4: Budget lines depicting COVID-19 Economic Reality

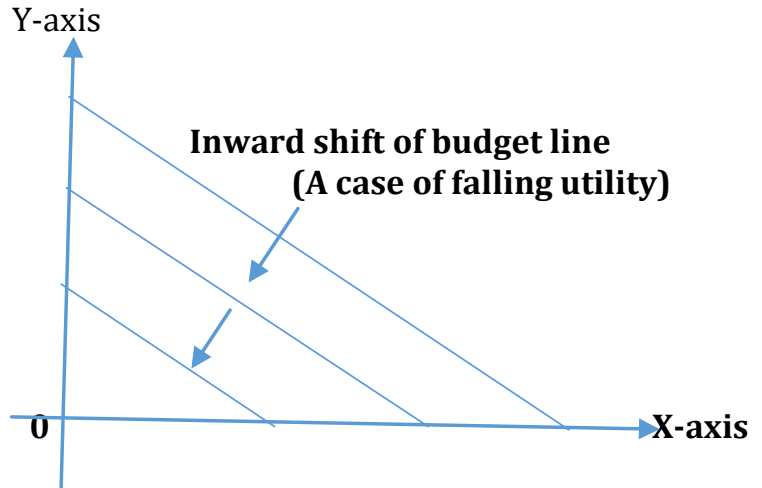

Given a significant variation in endowment such as initial saving, household consumption behavior will follow a kind of linear function under COVID-19 crisis. In this case consumption during the COVID-19 outbreak will only be driven by individual household or on aggregative basis, individual country's initial endowment. Some households or countries with low initial endowment will consume low during COVID-19 crisis and will be more severely hit than those with higher endowment. Similar view is shared in the work of Jonathan (2020) which stated emphatically that investment was low in the pre-crisis period and this cumulated to high death rate in the crisis period. The crisis therefore caused the inevitable recession which is believed to cause more deaths due to deterioration in physical and mental health, rising suicides and many related misfortunes associated with recession. Several causes of economic recession are documented in the literature particularly, Jagannathan, Kapoor and Schaumburg (2013), Petrakos (2014), Aisen and Veiga (2013, Lagravinese (2015), Giugni and Grasso (2016), Bernburg (2016), Larry (2020) and even, Keynes (1936). There is no doubt COVID19 pandemic could cause another major global economic crisis since the spillover effects are grievous on economic activities within countries and across countries of the world. Individual households within countries as well as individual countries across the globe differ in initial endowment and hence the effect of any recession might vary across board.

The worse scenario is a situation where the individual households' or individual countries' endowment is zero. This implies that the consumption during the COVID-19 crisis is only a linear function of current income since the initial endowment is zero. These situations can be depicted better using equations as better tools of analysis. Let consumption be expressed as a function of initial endowment and current income. The COVID-19 crisis affected all sources of income. Given a simple income model of the form

$Y_{t}=w_{t}+k_{t}+l_{t}+e_{t}$

Where

$w_{t}=$ wage income during the period $t$

$k_{t}=$ interest income during the period $t$

$l_{t}=$ rent income during the period $t$

$e_{t}=$ profit income during the period $t$

It is no gain say that during COVID-19, these various sources of income are blocked temporarily because of various measures put in place to prevent the spread of COVID-19 pandemic and this may shrink the aggregate income $Y_{t}$ for some and for some the current income $Y_{t}$ would have become zero.

The consumption function in the pre-covid 19 period takes the form

$C_{t}=A_{0}+\beta Y_{t}+\theta Y_{t-1}+u_{t}$ 
Where

$Y_{t}$ is the current income

$Y_{t-1}$ is the past income

$u_{t}$ is unobserved phenomenon otherwise called the error term in the consumption function

Equation (2) can only represent the condition of a limited set of people whose consumption depends both on the current and past income and which may be insignificant, hence the equation may thus be altered slightly by integrating the two period incomes together as determinant of current consumption and this becomes

$C_{t}=A_{0}+\phi\left(Y_{t}+Y_{t-1}\right)+u_{t}$

$\phi$ in equation (3) is the marginal propensity to consume which lies between zero and one.

That is, $0 \leq \phi \leq 1$ and $\phi=\beta+\theta$, hence, $0 \leq \beta+\theta \leq 1$

Where $\phi$ is closer to 1 , saving from both current and past income would be very close to zero if not zero, so also the endowment $\left(A_{0}\right)$. But

$A_{0}=f\left(Y_{t-1}\right)$

Endowment depends on savings from past income and where such tends to zero, then the endowment also approximate to zero that is, as $\phi \approx 1$, savings tends to zero likewise the endowment. However, in the COVID19 period, consumption may now be a dependable function of past income since the current income suddenly becomes zero due to the total shutdown of the economies across the globe which ground economic activities to zero in many countries of the world. So, the current income $Y_{t}$ suddenly approach zero and consumption function reduced to

$C_{t}=A_{0}+Y_{t-1}+u_{t}$

Since past income $\left(Y_{t-1}\right)$ determines the initial endowment $\left(A_{0}\right)$, so either of these would be used as explanatory variable in the consumption function, so, we have equation (5) becoming

$C_{t}=A_{0}+u_{t}$

As initial endowment $A_{0}$ tends to zero,

$C_{t}=u_{t}$

Both initial endowment and current income affect onsumption behaviour of individual household and individual countries at aggregative level. Let equations 3,6 and 7 be three cases represented by $C_{1}, C_{2}$ and $C_{3}$ with $C_{3}<C_{2}<C_{1}$. In this case, $C_{3}$ is more badly hit with COVID-19 pandemic and is more apprehensive of the hunger virus which is the opportunity cost of the corona virus. Unless people in this category are reached by any of the palliatives put in place to cushion this shortfall, there is tend ency for hunger virus to wreck havoc. Graphically, this situation is illustrated in Figure 5 depicting consumption as linear function of current income and initial endowment. $0 \mathrm{C} *$ is the autonomous consumption, it is consumption when income is zero. It is very important to note that while income can be zero, consumption cannot be zero, hence, consumption line does not emerge from the origin. At current income $0 \mathrm{Y}_{1}$ and initial endowment $\mathrm{I}_{1}$, consumption is $0 \mathrm{C}_{1}$ at point $\mathrm{P}_{1}$, at current income $0 \mathrm{Y}_{2}$ and initial endowment $\mathrm{I}_{2}$, consumption is $0 \mathrm{C}_{2}$ at point $\mathrm{P}_{2}$, at current income $0 \mathrm{Y}_{3}$ and initial endowment $\mathrm{I}_{3}$, consumption is $0 \mathrm{C}_{3}$ at point $\mathrm{P}_{3}$, at current income $0 \mathrm{Y}_{4}$ and initial endowment $\mathrm{I}_{4}$, consumption is $0 \mathrm{C}_{4}$ at point $\mathrm{P}_{4}$, but $0 \mathrm{C}_{1}<0 \mathrm{C}_{2}<0 \mathrm{C}_{3}<0 \mathrm{C}_{4}$. Individual households and countries with low initial endowment would be more hit than those with higher endowment. Endowment is a function of saving from past income. Where saving is absolutely zero, endowment is equally zero. As income rises, there is tendency for saving and endowment to rise. In low income countries, or among low income earners, there is tendency for saving and endowment to be equal to zero putting undue pressure on countries or people in this category to meet up with daily consumption requirement that triggered into crises during the COVID-19 pandemic. 


\section{Figure 5: Consumption Function}

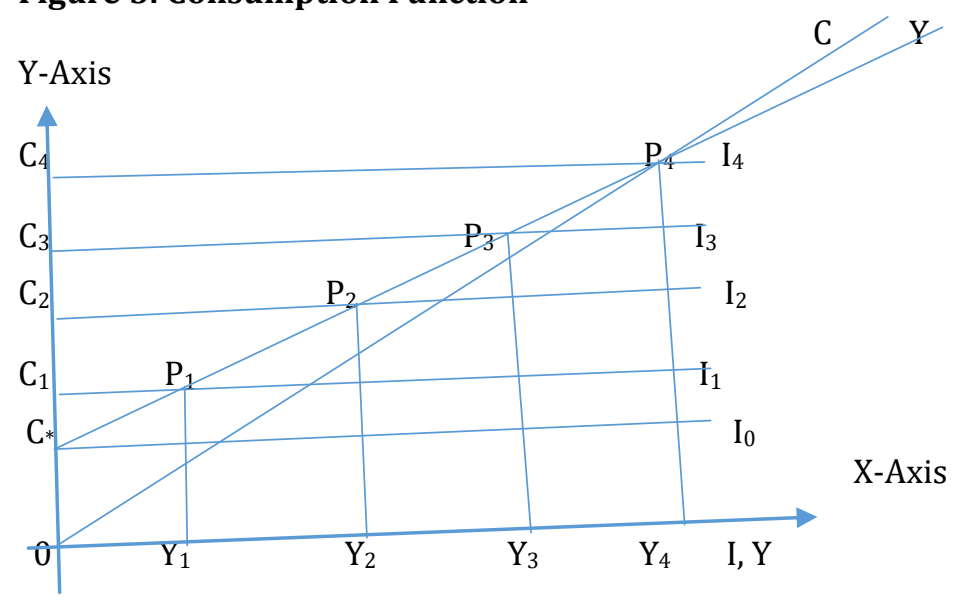

Analysis of COVID-19 Pandemic, the Fiscal Stimulus and Efficiency Scenario

Since the outbreak of COVID-19 global pandemic, governments from various countries have engaged in one kind of fiscal stimulus or the other to cushion the effect. Some empirical evidence on the use of fiscal stimulus to cushion the effect of COVID-19 pandemic are provided in the works of Ozili (2019) as well as Ozili and Arun (2020). In some countries cash was given out to the citizen to smoothen out consumption to fill the income gap due to lockdown and stay at home order which keep people out of employments. Incomes from employments become very unrealistic due to shutdown strategy to contain the deadly virus. Many countries applied the shutdown strategy and this put all forms of economic activities to a halt with exception of few that have to do with essential commodities such as foods, medicines and other life-supporting goods and services. This strategy has kept many people out of employments and since consumption is a must, government provisions in form of sharing.

In cash and kind to the people concern become necessary in some countries, the fiscal stimulus comes in form of palliatives such as foods, water, medicines and the likes. In some countries, it comes in form of cash. The efficiency of these various government interventions across countries, can not only be determined on the basis of accessibility and delivery strategy to individual households that are worse hit by this deadly virus but also by initial saving condition of the people. It also depends on the proportion of population covered in the sharing and the ease of distributing these palliatives. In some countries the mode of sharing the palliatives was so fantastic, well organized without necessarily causing violation of the social and physical distancing rule which is the major objective of stay at home and lockdown rule to avoid the spread of the virus. In some countries, it was like a thug of war, the atmosphere was that of chaos and struggle leading to the breaking down of physical distancing rule as people struggle to get their share since the laydown rule has been broken and no one is ready to wait and see what is being shared finished while still on the queue for the fear of hunger. This quickly revealed the trade-off behavioral patterns between corona virus and hunger virus of many households who risk corona to avoid hunger for the fear of hunger virus is the beginning of wisdom.

This behavior is a proof of the reveal preference theory. The preference for food and other life-sustaining goods and services are strong indeed that people prefer to sacrifice the chance of being invulnerable to corona virus for the chance of being vulnerable to hunger virus. This revealed preference testifies to the fact that there is high incidence of poverty in many countries especially under-developed countries and if the world is really a global village, it should be of great concern to many of the rich and highly developed countries in this so-called global village to urgently do something on how to re-distribute the world resources to reduce the incidence of poverty so that everyone can have access to the basic life-sustaining goods such as food and water for COVID-19 scenario has revealed that people fear hunger a times more than any deadly virus. The resistance to lockdown in most less developed countries was caused by fear of hunger as people lack the basic needs of sustenance due to absence of savings. People lives from hand to mouth, they depend on daily income to take care of daily consumption. In the absence of saving, the lockdown rule would 
definitely mean eternal hell to people in this category and there will be a great resistance to lockdown rule from people whose marginal propensity to consume is almost 1 .

This also might be the reason for crime rate to be very high since people prefer to take some risk of indulging, in illegal businesses or transactions for the little income gain associated with such behavior, just for them to survive. Reduction in global poverty may also help to reduce the global crime rate as it were especially in the post-COVID-19 era. The trade-off between hunger and corona virus is determined by the marginal propensity to consume and marginal propensity to save. Figure 6 depicts the relationship between the marginal propensity to consume and the marginal propensity to save. The relationship is negative as the slope of the line graph is negative. When the marginal propensity (mpc) is one, the marginal propensity to save (mps) is zero and there is high tendency for people to resist the lockdown ready to trade-off hunger for corona virus. In this case, people prefer to take the risk of corona virus by boycotting the lockdown rule instead of stay indoors and risk hunger. On the other hand, when the marginal propensity (mpc) is close to zero, the marginal propensity to save (mps) is close to one and there is high tendency for people to obey the lockdown to avoid the risk of corona virus infection because there is hope of having access to food and some lifesustaining goods guaranteed by initial saving. During the COVID-19 and the lockdown experience, the demand only changed in favor of necessity mainly food and other life-sustaining items. People manage what they have on necessity and the demand for luxury becomes automatically zero. At various points on the line where marginal propensity to consume or to save is in-between 0 and 1 , especially at points $\mathrm{M}$ and $\mathrm{N}$ there is trade-off between hunger and corona virus. In this case, the preference to take risk of corona virus decreases as marginal propensity to save increases towards 1 or tends towards unity.

It is important to note that the behavior of households is governed by the ability to meet daily obligation as nature imposed on man, so, any policy of government will suffer less resistance especially in poverty-stricken regions of our world if policy maker can engage in policy strategy that boost income of so-called poor masses so as to enhance the marginal propensity to save and reduce the marginal propensity to consume. This makes lives to be more meaningful and secured especially during emergency; people can still exhibit a normal behavior and make governance easier for those in government. Policy makers should know that, it is much easier to manage and govern someone who exhibits a normal behavior than to manage and govern someone who exhibits abnormal behavior caused by hunger and social exclusion. A growing concern for health would definitely reduce wealth outcome while on the other hand, a growing concern for wealth has serious implication on health outcome. The citizens in different countries are calling for easing the lockdown rule to boost wealth outcome but the authorities are looking at the opportunity cost in term of health outcome. Authorities would have loved to create wealth by easing the lockdown rule if the probability that such a decision will not jeopardize the public health is high. So, there is unhealthy competition between decisions to create public wealth at the expense of protective public health. The choice is to be made between protective public wealth and protective public health. To make the optimal choice in this case, authorities need to first find out if there is a cause-effect relationship between wealth and health asset of citizens. They must strike a balance between wealth and health asset. Figure 7 shows the trade-off between wealth and health assets. At point $\mathrm{A}$, health is absolutely considered by the authorities in easing the lockdown rule, no consideration for wealth asset. Also, at point B, wealth creation is solely considered in the decision to ease the lockdown, there is no consideration for health asset.

The decision at points A and B may be undesirable considering the general saying which says "health is wealth" and the possibility of a reverse causation which affirms the statement that says "wealth is health". The first statement which states that "health is wealth" emphasized the role of health in wealth creation while the second statement that reads "wealth is health" underscored the role of wealth asset in creating health asset. A hungry man is a sick man, so, hunger virus may be as deadly as corona virus. This is supported by the kind of heavy protests and resistance by people across countries of the world against lockdown and stay at home rule. People demonstrate their displeasure with total lockdown because of greater opportunity cost associated with this. Domestic violence against women, children and the vulnerable were reported in many countries due to continuous lockdown rule. Government across countries have no choice than to begin to shift ground on the total lockdown rule since economic health of individual goes a long way to determine general condition of health of such individual. So, health is not defined from the perspective of biological health alone, 
the overall state of health of an individual is determined not only by biological health but also by economic health, psychological health, mental health, social health and spiritual health.

The lockdown rule has created an unusual mode of protecting biological health but in jeopardy of economic, psychological, mental, social and spiritual health of the people. See, Davillas and Jones (2020), Chatterji and Li (2020), Tubadji, Boy and Webber, (2020), de Pedraza, Gusi and Tijdens (2020), among others for further exposition. Authorities' attempts to protect biological health of citizens are seeing to be counterproductive since they are indirectly jeopardizing economic, psychological, mental, social and spiritual health. Public health safety therefore should not be seen parochially from biological health point of view alone but holistically from point view of economic, social, psychological, mental and spiritual health. From Figure 7, authorities must give consideration to both wealth and health assets. Operating at point G implies a trade-off between health and wealth asset. Instead of $0 \mathrm{~A}$ of health asset with zero of wealth asset, we now have $0 \mathrm{~F}$ of health asset combine with $0 \mathrm{~K}$ of wealth asset. Authorities are considering taking some health risk to get some economic gain so that the pain associated with sudden loss of wealth can be healed gradually.

Figure 6: Hunger and Corona Virus Trade-Off (mps and mpc nexus)

Y-axis

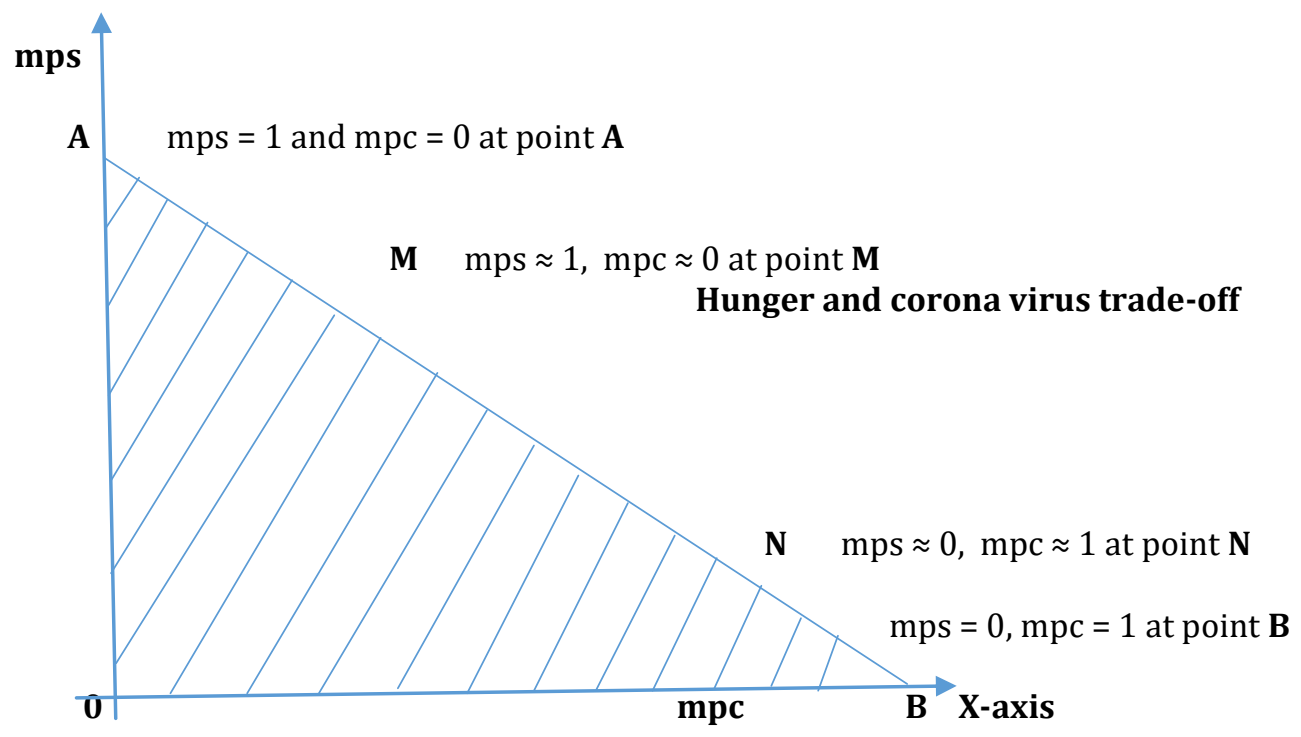

Figure 7: Wealth and Health Asset Trade-Off (Wealth versus Health Consideration)

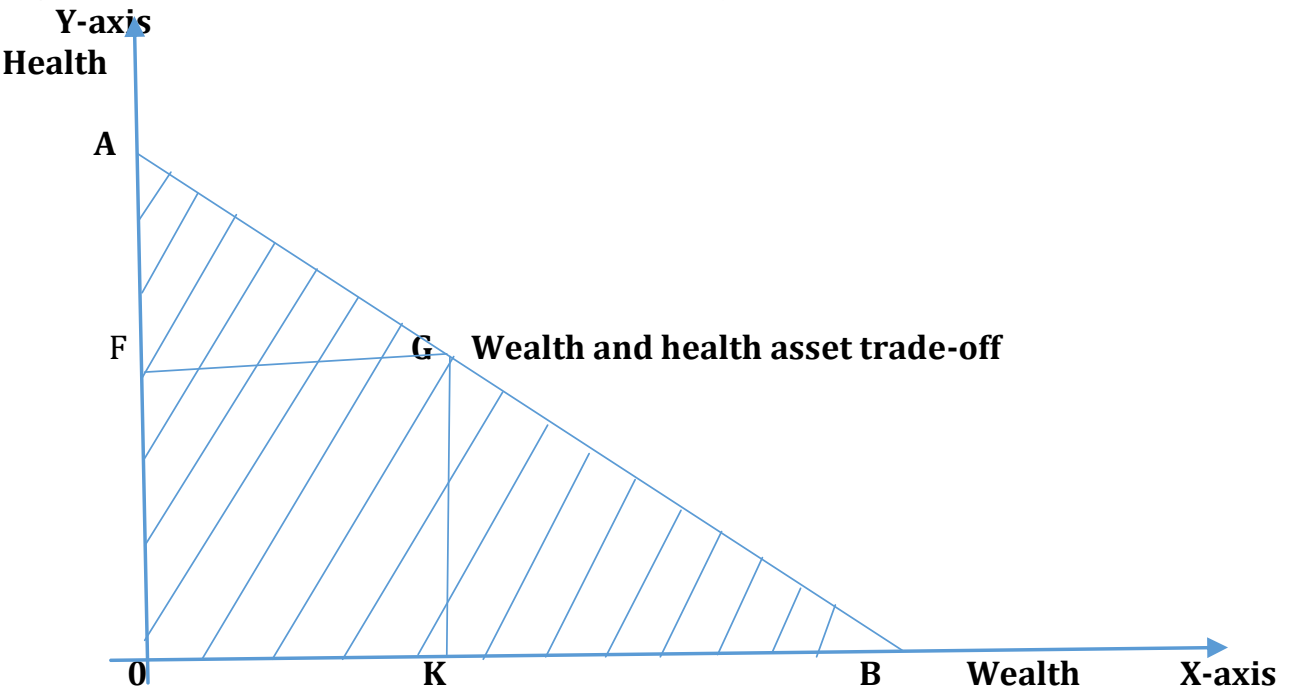




\section{Strategies that could be employed to cushion the Effect of COVID-19 on the Economy}

There is no gain say in the fact that COVID-19 has ruined the world economy. Studies such as Ozili (2019), Ozili and Arun (2020) and Larry (2020) among others have provided some details in support of this view. The world is of age and it is generally believed that experience is a function of age. As one grows older each day, experience is gained. The experience of global economic melt-down occurred in the 1930s following the crash in stock prices in 1929. It also occurred in the 1970s as well as 2008 that of the 1930s is often referred to as the Great Economic Depression in history, with the failure of invisible hand to resolve the unemployment crisis for supply failed to create its own demand and unemployment problem persist before the Keynesian interventionism. The current experience might be a worse scenario considering the number of deaths and expected changes that may take place in the world system due to this pandemic. Only time and events could tell whether the situation could be described to be worse than the experience of the so-called global economic melt-down of 1930s.

Policy makers, health experts and economists as well as concerned stakeholders have been brainstorming on the best strategy to address many problems that this pandemic has caused for the entire mankind living in developed and under developed countries. This pandemic has separated us more than any war could have done, America is closed against Europe, Asia is shutdown against Africa, Australia is now only for Australian, no entry of nationals from other countries, this is the greatest separation in history, it happens from world level to continental level to individual country level to regional level to state level within country to local or county level within state to ward level within local or county area, and there is an adage which says in unity lies strength. International and regional or international trade suddenly becomes history in our new world as autarky becomes the order of the day. This pandemic is a threat to our economic and social existence. It has crippled economic activities putting too much pressure on government finances since government stimulus including social security expenditure would definitely pushed government to spend above her revenue leading to fiscal deficit. The revenue earning power of government has falling while the need to hike expenditure has plausibly materialized.

Borrowing may become a necessary source of raising funds to finance the deficit. This has a great implication on debt burden especially in countries with high debt profile even before COVID-19. Living a solitary life is alien to our world system. Kissing, hugging and handshaking suddenly become an aberration, face to face talk without the use of facial mask suddenly become forbidden. The group life, in our mode of worship, our market places especially in less developed countries, in entertainment and sports arena, etc. has become threatened and we are yet to know whether the status quo is still possible or whether a paradigm shift has finally occurred. The role of government in the management of the economy cannot be over-emphasized especially during this period of time when the economy crashed into a recession and finally looms in depression. Millions of people across the globe are now out of employment, many businesses have been shut down, millions of people have been infected and are under treatment and yet to know their fate though the recovery rate is a little bit impressive in some countries, hundreds of thousands of people who could either have been job providers or highly skilled employees have died resulting to human capital loss to the economy. It takes time and use of highly competitive resources to train people to replace the lost wealth of experienced individuals who have been a victim of corona virus. What can be done is the adoption of pulling strategy, in which global resources are pulled together and allow to spread out to cover the entire countries in the space such that the effect will not be too heavy in one region and we can share the whole burden and lighten it away to regain our lost world from the corona virus. The world needs to intensify the need to expand access to online digital technology so that our world can be more connected electronically given the constraints. Electronic exchange can be facilitated through digital technology to generate online employment and income for the households. The broader online digital technology access can help to ameliorate the effect of COVID-19 if it is widely available to everyone irrespective of countries or region of births. This is the time to deal with the problem of digital divides between the rich and poor nations of the world as well as between the rich and the poor individuals living in each country of the world. Both monetary and fiscal measures are also needed in this trying period. See, Gourinchas, (2020), Abel, et al. (2020), Bianchi, Faccini and Melosi (2020) for detail exposition on these measures. 
It is also important that monetary policy be conducted in such a way that the monetary policy rate would be optimally decided in line with the economic reality. Interest rate should be so low to encourage new investors to take up investment opportunities available in the post-COVID-19 period. Fiscal stimulus to households and business firms should continue until the economic activities are fully restored so as to prevent the collapse of household and business sectors. All forms of taxes including the value added tax (VAT) should be suspended for now to allow the economies to pick up again. It is glaring that in this kind of period, there is need for budget deficit and where the finances occurs through borrowing, it poses a high debt burden on the economy. Most of the countries' debt profile has grown up rapidly and becomes very abnormal in this COVID-19 period, it is very important for debt re-scheduling and debt forgiveness to lessen the burden imposed by the COVID19 pandemic. The creditors either group of lenders or international financial institutions should consider poor and highly vulnerable countries for debt forgiveness to enable them rebuild the downturn economy. The post-COVID-19 world leaders should be watchful of on-going events and activities in another countries and should be able to pull global resources together to track any unhealthy move that could be a threat to the global existence. As we can see, every nation of the world has paid and is still paying their own prices during the COVID-19 pandemic. No nation is spared in the pain and setback caused by the pandemic which has changed the behavioral pattern of our known world and gives us a new world of strange behavior with her socio-economic mal-adjustment. The time has come when countries of the world must be ready to pay their due diligence in their oversight function to ensure the activities going on in one country will not come back to become a burden or a price that the whole world community would inevitably force to share. The desire to achieve speedy economic progress by any country should not be done in jeopardy or at detriment of our global existence. No nation in the world is spared by COVID-19, meaning that every nation would have paid their own prices in whatever form. It would have been better to go for the use of defensive approach rather than offensive for prevention is better than cure. The world could have been better off if COVID-19 has been detected earlier and captured without allowing its spread. The world would have witnessed a few or no victim.

More importantly, the missing link in human achievement is the fact that man usually fail to acknowledge the supreme authority over every achievement. The truth of the matter is that no success or failure without the supreme authority. Whenever experienced a shock, man, in most cases bother not to search for the cause beyond humanly possible scientific approach. Models are mostly tailored towards a scientific school of thought whereby every shock must have humanly possible explanation which can be explained scientifically and where such solution is ineffective or is not even readily available, man have always failed to use the only left available option which is the supreme authority. Man from generation to generation have preferred carnality to spirituality in their efforts to rescue humanity. On many occasion, it never works that way since many of the problems facing humanity first appear in the spirit and must be first of dealt with in the spirit. God is the supreme authority and whenever there is a shock above human explanation, man should be ready to immediately do away with pride and seek divine intervention to get to the root of the problem. God is the owner and giver of all knowledge, any nation or group of nations leading the world today may not be the one to be in charge tomorrow because, the Giver has the power to change who the leader should be at every point in time. If God has not given you such power and you want to have it at all cause, you will be disappointed because it will lead to destruction. Although God has given man power to do things that are super through research and innovation and many a times.

It takes some time before scientists have breakthrough over many discoveries, for instance Charles Babbage invented analytical engine which failed to work during his life time but began to function one hundred years after, leading to the development of modern day computers. One cannot over-emphasize the benefits of computer to human existence on the planet earth today. God in His infinite Mercy has always being supportive to man in their efforts to make further discovery of many hidden phenomena that will be of mutual benefits to the entire world but man must not fail to remember God first in any event so that God can give man a direction to follow in achieving great things. In this COVID-19 pandemic, the world leaders should always remember to put God first whenever they seek solution so that the suffering of mankind from any negative effect of shock can be minimized because of prompt intervention of God who can unfold things that are in the secret and give the world leaders the direction to go so that they would not have suffered unnecessarily for too long. If leaders would seek God earlier in emergency, it would minimize the pain and 
hardship on their subjects since God prompt intervention is enough to have given the leaders the direction to take to get out of the problem. A blind leader is a curse to the followers and the consequence is grave.

Using a simple econometric model to explain this better,

Suppose

$G_{t}=G_{0}+\Omega H_{t}+U_{t}$

$G_{t}$ represents the global phenomenon which can be explained by $H_{t}$ and $U_{t}$

Where

$H_{t}=$ the known factor determining global phenomenon $G_{t}$, and

$U_{t}=$ unobserved factor deternining $G_{t}$

This unobserved phenomenon is not under the control of the modeller and it is the one that will really determine whether the model has done well or not. If $H_{t}$ represents all the known factors affecting $G_{t}$, then $U_{t}$ represents the unknown factors or unobserved factors which could be likened to the supreme authority, the invisible hand that rules the universe. As the modeller diagnosed $U_{t}$ to find out how well the model explains the phenomenon it sets to explain, $G_{t}$ in this case, man also need to always consult God in unfolding unforeseen events. This is where the need to consult God first hinged on. For without God, man cannot achieve any reasonably good thing in this life, so in dealing with coronal virus, there is nothing stopping every leader in their respective country, despite the medical reinforcement put in place, to still go extra mile by declaring one day, two days or three days of prayer to seek the help of God to wipe out corona virus in every corner of our world so that lives can be worth living. With the number of deaths recorded on daily basis in many countries caused by COVID-19 pandemic. See, John Hopkins University (2020a, April); John Hopkins University (2020b, May)

There is the need for the world leaders to consider spirituality as a viable option in their struggle to stop this unusual deaths and to destroy corona virus completely. A virus is a microbe. It is one of the many microscopic organisms found in the animal kingdom as created by God and I am sure corona virus is not created today and even if this particular one is a man made virus, who created man itself? If it is a man-made virus, God is the supreme authority who can handle situation that become too scary and unmanagable to man. For God to help us in the time like this, we need to turn to Him and humble ourselves before Him. We must have faith in Him and trust Him completely. He will surely surprise us and show us mercy. Corona virus, whether naturally made or man-made, will be deactivated and distroyed completely by our God, who is the chief controller of the universe, so that we can have our normal world back. God, who created all viruses is absolutely powerful enough to deal with any virus that want to dislodge humanity away from the planet earth. Without any weapon of war, without ordinary guns, or machine guns or any missile, ballistic or cruise missile, the world has recorded about four hundred thousand deaths with over four million people infected between December 2019 and May 2020, just in less than half of a year. It is high time the world leaders led their followers back to their maker to retain our world of modesty, peace and healthy living. In the time like this, when human solution or intervention becomes less effective, too slow and weak, grossly inadequate or atimes failed to yield the desire results, man must scale up the hope and faith in their Creator and go absolutely for Divine Solution.

\section{Some Lessons Learnt against Future Occurrences}

COVID-19 has exposed the vulnerability of all nations to any eventuality. It has taught us the lessons of our lives that God is supreme in all events. It is only God that can be said to be untouchable, unbeatable, infallible and unthinkable. Before the outbreak of COVID-19, nobody could ever thought of it that something of this nature could happen that would have overwhelmed our big nations, the so-called technologically advanced and developed countries of the world who have so much to give to counter unforeseen events and to checkmate its attendant consequences. It is important to put more of our trust in God's provision than manmade provision which can fail or disappoint us at a time we least expected. Technology can fail, knowledge can fail, power can fail, human medical prescription can fail but God can never fail. When all humanly designed mechanisms failed, we learnt that we should not hesitate to seek God who stands on top of all problems or challenges. It should be noted that the permanent solution to COVID-19 pandemic is God, once we call God to intervene in the battle against corona virus, the virus dies a natural death and the end of 
COVID-19 pronounced. God's solution is permanent and once God decrees to end the corona virus, all is over, no second wave, or third wave upsurge in corona virus death or infection.

The COVID-19 period shows a significant, dreadful and abnormally high mortality rate in developed countries where human lives are just so special and valuable. Hospitals were overwhelmed, mass burials were found as if lives worth nothing again. See the latest update of deaths, infection and recovery rates in John Hopkins University websites. The lesson is also learnt that nothing is permanent, we saw how a world of global village suddenly turned to a world of isolated cities. Life is short and hence should be treated as such, no man can accurately predict tomorrow, we own today but tomorrow is not under our control so whatever we can do today should not be postpone till tomorrow because only God knows what tomorrow looks like. Among people that have died in this COVID-19 period, many would have had some proposals for this year and years ahead but which the sudden event of COVID-19 pandemic would not have allowed them to implement such proposals. Many people that have become unemployed today never thought it could happen because there was no signal or pre-information for anybody to stay out of being a victim. Many CEOs, most especially those from the aviation sector never thought their organizations will dry up shortly before the end of first half of year 2020 but they are all victims of reality. During COVID-19 period, home becomes the safest spot to stay safe, hence, it is important to ensure we secure a healthy and ideal home because whenever there is emergency, we will have a secure place to stay safe. This should also remind us of our heavenly home, after the journey to this world is over, we must surely return home, so every witness of COVID-19 pandemic should always be mindful of how they are building there eternal home so as to stay safe eternally at the end of their journey in this world. Do you really have a home? A food for thought.

The wide inequality between the rich and the poor proved unnecessary during COVID-19 period since the need of both reduced barely to the basic need such as food and other life-support goods and services, all put together as necessity, no room for luxury. The markets for luxury were shutdown since at this time, demand for luxury has temporarily become zero. The lockdown and stay at home rule almost equate everybody. The gorgeous clothes in the wardrobes of many rich people, the shoes, exotic cars, and many luxurious goods become temporarily useless in the COVID-19 era where everybody was mandated to stay in his/her home, no social gathering of any kind, no party nor club meetings, no travel, whether interstate or international, all tourist centers closed, all sport schedules postponed, etc. The main objective of every government is how to get rid of corona virus. Health sector attracted so much of private and government spending. A lot of money went into the sector to boost health infrastructure to be able to contain the corona virus. Health workers received better attention and motivation to put in their best in the fight against the deadly virus. Life is short and hence should be treated as such, no man can accurately predict tomorrow, we own today while tomorrow is not under our control so we should not procrastinate whatever we can do today.

Moreover, It becomes glaring that the pre-COVID-19 health sector in many countries was underfunded and hence, deficient, in infrastructural capacity to respond favorably well during emergency. It is important to be proactive instead of being reactive, prevention is better than cure. People should also learn how to conserve during the period of surplus because we cannot predict what comes next. Those that have good culture of saving were better off during COVID-19 than those that eat all. Eating all means zero saving, all consumption. There is need to make provision for the raining day as depicted in the liquidity theory developed by Lord Maynard Keynes. One of the three motives for holding money is precautionary motive which has to do with unforeseen contingencies like sudden events such as natural disaster, sickness, and pestilence, just like the COVID-19 that just came suddenly and reduce the world to a death factory. It must be said at this point in time, this present world is not a permanent home and man should desist from unusual habit of holding this world as a permanent place of abode. Resources of this world should be shared so that everyone can live a minimal lives expected of a normal person. There is no need for frivolous and conspicuous consumption. Authorities therefore should device ways of pulling global resources together to fight poverty just as the world is fighting this corona virus since poverty itself is a common virus responsible for many abnormal and anti-government behavior in our world.

\section{Conclusion:}

This paper examined the socio-economic changes and behavioral maladjustments following the outbreak of a viral disease popularly known to be COVID-19 with its origin traced to Chinese city of Wuhan. The outbreak 
was learnt to begin towards the last quarter of the year 2019 but the cause was yet to be unfold by the world powers only for the effects to have been found in every country across the globe. The paper discussed the demand and supply shocks resulting from the pandemic as well as the efficacy of the fiscal stimulus provided by the government to cushion the effect on the people and the economy. The post-COVID-19 implication of this high government expenditure regime which is mainly a regime of fiscal deficit on debt burden especially in countries with high debt profile even in the pre-COVID-19 period was critically examined. The paper underlying some of the damages done to the socio-economic lives of people across the globe and highlight recovery strategies with some lessons learnt and future prospects. The paper therefore concluded that the memory of the shocks created by COVID-19 pandemic may stay longer than expectation but could have proved the supremacy of God and the state of helplessness of man in some unforeseen events as a microbe of invisible property reduced our world of global village to a world of isolated cities.

\section{References}

Abel, B., David, G., Anik, I. \& Suraiya, J. B. (2020). A Literature Review of the Economics of COVID-19. IZA Institute of Labour Economics, Discussion Paper Series, IZA DP No, 13411. www.iza.org

Adeniran, A. 0., \& Sidiq, B. 0. (2018). Economic recession and the way-out: Nigeria as case study. Global Journal of Human Social Science, 18(1), 181-192.

Aisen, A. \& Veiga, F. J. (2013). How does political instability affect economic growth? European Journal of Political Economy, 29, 151-167.

Atkeson, A., Kopecky, K. \& Zha. (2000). Estimating and Forecasting Disease Scenarios for COVID-19 with an SIR Model (Working Paper No. 27335; Working Paper Series).

Bagliano, F. C. \& Morana, C. (2012). The Great Recession: US dynamics and spillovers to the world economy. Journal of Banking \& Finance, 36(1), 1-13.

Berger, D. W., Herkenhoff, K. F. \& Mongey, S. (2020). An SEIR Infectious Disease Model with Testing and Conditional Quarantine (Working Paper No. 26901; Working Paper Series). National Bureau of Economic Research. https://doi.org/10.3386/w26901

Bermeo, N. \& Bartels, L. (Eds.). (2014). Mass politics in tough times: opinions, votes and protest in the Great Recession. Oxford University Press.

Bernburg, J. G. (2016). Economic crisis and mass protest: The pots and pans revolution in Iceland Routledge.

Bianchi, F., Faccini, R. \& Melosi, L. (2020). Monetary and Fiscal Policies in Times of Large Debt: Unity is Strength (Working Paper No. 27112; Working Paper Series). National Bureau of Research. https://doi.org/10.3386/w27112

Blanchard, O. J. \& Quah, D. (1989). The dynamic effects of aggregate demand and supply disturbances. American Economic Review 79, 655-673.

Chatterji, P. \& Li, Y. (2020). Effects of the COVID-19 Pandemic on Outpatient Providers in the US (Working Paper No. 27173; Working Paper Series). National Bureau of Economic Research, https://doi.org/10.3386/w27173

Chauffour, J. P., \& Farole, T. (2009). Trade finance in crisis: market adjustment or market failure? The World Bank.

Dada, M. A (2013). Empirical Investigation of Government Expenditure and Revenue Nexus; Implication for Fiscal Sustainability in Nigeria. Journal of Economics and Sustainable Development, 4(9), 135-146.

Dalena, M. \& Magazzino, C. (2010). Public expenditure and revenue in Italy, 1862-1993, MPRA Working Paper, 27658, http://mpra.ub.uni-muenchen.de/27658/.

Dasaratha, K. (2020). Virus Dynamics with Behavioral Responses. ArXiv: 2004.14533 [Econ, q-Bio]. http://arxiv.org/abs/2004.14533.

Davillas, A. \& Jones, A. M. (2020). The COVID-19 pandemic and its impact on inequality of opportunity in psychological distress in the United Kingdom (ISER Working Paper Series No. 2020-07). Institute for Social and Economic Research. https://econpapers.repec.org/paper/eseiserwp/2020-07.htm

de Pedraza, P., Gusi, M. \& Tijdens, K. (2020). Life Dissatisfaction and Anxiety in COVID-19 pandemic [MUNI ECON W/Paper].Masaryk University.https://econpapers.repec.org/paper/mubwpaper/2020-03.htm

Di Quirico, R. (2010). Italy and the global economic crisis. Bulletin of Italian Politics, 2(2), 3-19.

Eichenbaum, M. S., Rebelo, S. \& Trabandt, M. (2020a). The Macroeconomics of Epidemics (Working Paper No. 26882; Working Paper Series). National Bureau of Economic Research. https://doi.org/10.3386/w26882 
El-Erian, M. (2020). The Coming Coronavirus Recession and the Uncharted Territory beyond Foreign Affairs, Media Report. Available at: https://www.foreignaffairs.com/articles/2020-03-17/comingcoronavirus-recession.

Financial Times. (2020). Global recession already here, say top economists. Available at: https://www.ft.com/content/be732afe-6526-11ea-a6cd-df28cc3c6a68.

Giannakis, E. \& Bruggeman, A. (2017). Economic crisis and regional resilience: Evidence from Greece. Regional Science, 96(3), 451-476.

Giugni, M. \& Grasso, M. T. (2016). Austerity and protest popular contention in times of economic crisis, Routledge.

Glassman, J. (2001). Economic crisis in Asia: The case of Thailand. Economic Geography, 77(2), 122-147.

Gourinchas, P. O. (2020). Flattening the pandemic and recession curves. Mitigating the COVID-19 Economic Crisis: Act Fast and Do Whatever. http://viet-studies.net/kinhte/COVIDEconomicCrisis.pdf\#page=38

Grasso, M. T. \& Giugni, M. (2016). Protest participation and economic crisis: The conditioning role of political opportunities. European Journal of Political Research, 55(4), 663-680.

Honkapohja, S., \& Koskela, E. (1999). The economic crisis of the 1990s in Finland. Economic Policy, 14(29), 400-436.

Horowit, J. (2020). The global coronavirus recession is beginning. CNN. Media report. Available at https://edition.cnn.com/2020/03/16/ economy/global-recession-coronavirus/index.html

Jagannathan, R., Kapoor, M. \& Schaumburg, E. (2013). Causes of the great recession of 2007- 2009: The financial crisis was the symptom not the disease. Journal of Financial Intermediation, 22(1), 4-29.

John Hopkins University. (2020a, April). New Cases of COVID-19 in World Countries, John Hopkins Coronavirus Resource Centre. https://coronavirus.jhu.edu/data/new-cases.

John Hopkins University. (2020b, May). Mortality Analyses, John Hopkins Coronavirus Resource Centre. https://coronavirus.jhu.edu/data/mortality.

Jonathan, M. (2020). The covid-19 crisis - and the future of the economy and economics, International Review of Applied Economics, 34:3, 301-303, DOI:10.1080/02692171.2020.1756040. https://doi.org/10.1080/02692171.2020.1756040.

Kermack, W. O., McKendrick, A. G. \& Walker, G. T. (1927). A contribution to the mathematical theory of epidemics. Proceedings of the Royal Society of London Series A Containing Papers of a Mathematical and Physical Character, 115(772), 700-721.

Keynes, J. M. (936). General Theory of Employment, Interest and Money, London: Macmillan.

Krueger, D., Uhlig, H., \& Xie, T. (2020). Macroeconomics Dynamics and Reallocation in an Epidemic (Working Paper No. 27047; Working Paper Series). National Bureau of Economic Research. https://doi.org/10.3386/w27047.

Lagravinese, R. (2015). Economic crisis and rising gaps North-South: evidence from the Italian regions. Cambridge Journal of Regions, Economy and Society, 8(2), 331-342.

Larry Elliot, L. (2020). Prepare for the coronavirus global recession. The Guardian. Media report. Available at: https://www.theguardian.com/business/2020/mar/15/prepare-for-the-coronavirusglobalrecession.

Morales, J. A., \& Sachs, J. D. (1989). Bolivia's economic crisis. In Developing country debt and the world economy (pp. 57-80). University of Chicago Press.

Ozili, P. K. (2019). 100 Quotes from the Global Financial Crisis: Lessons for the future. Available at SSRN, 3500921.

Ozili, P. K. \& Arun, T. G. (2020). Spillover of COVID-19: impact on the Global Economy. Working paper.

Quaas, G. (2020). The reproduction number in the classical epidemiological model. Working Paper No. 167. Working Paper. https://www.econs.eu/handle/10419/216820.

Petrakos, G. (2014). Economic crisis in Greece. European and domestic market and policy failures. Région et Développement, 39, 9-33.

Stiglitz, J. E. (2010). Interpreting the Causes of the Great Recession of 2008. Financial system and macroeconomic resilience: revisited. Bank for International Settlements.

Tubadji, A., Boy, F. \& Webber, D. (2020). Narrative economics, public policy and mental health. Centre for Economic Policy Research, 20, 109-131.

World Economic Forum. (2020, March). A visual history of pandemics. World Economic Forum. https://www.weforum.org/agenda/2020/03/a-visual-history-of-pandemics/ 